\title{
HELMINTHOLOGICAL SURVEY IN THE 3RD DIVISION, SARAWAK (BORNEO), MALAYSIA
}

\author{
TOMIHIRo KURAHORI* SHOzo INOKI* AND TAKAFUSA NISHIKAWA** \\ *Research Institute for Microbial Diseases, Osaka University, Suita, Osaka-Fu, Japan, \\ **Osaka Prefectural VB Clinic, Osaka, Japan
}

In summer, 1969, the 6th Medical Mission of Osaka University attempted the medical surveys around Kapit area (three Iban villages) and upper Rajang (one Punan village), the 3rd Division, Sarawak. For the helminthological survey, ova of the parasites in feces were examined by both thin and thick smear methods. Species determinations of the hookworms were routinely carried out applying the culture method in test tube.

The numbers (percentage) of the infected peoples with the intestinal helminthes are shown in Table 1.

Table 1.

\begin{tabular}{lrrrrrl}
\hline \multicolumn{1}{c}{$\begin{array}{c}\text { Village } \\
\text { surveyed }\end{array}$} & $\begin{array}{c}\text { No. of } \\
\text { samples }\end{array}$ & Roundworm & Hookworm & Whipworm & Pinworm & $\begin{array}{c}\text { Dwarf } \\
\text { tapeworm }\end{array}$ \\
\hline Jitang*** & 115 & $89(77 \%)$ & $49(43 \%)$ & $62(54 \%)$ & $0(0 \%)$ & $0(0 \%)$ \\
Nyua*** & 104 & $93(89 \%)$ & $58(56 \%)$ & $67(64 \%)$ & $2(2 \%)$ & $1(1 \%)$ \\
Entap*** & 139 & $129(93 \%)$ & $83(60 \%)$ & $67(48 \%)$ & $2(1 \%)$ & $1(0.7 \%)$ \\
Kupak-kanyan**** & 193 & $148(77 \%)$ & $34(69 \%)$ & $123(64 \%)$ & $0(0 \%)$ & $0(0 \%)$ \\
\hline \multicolumn{1}{c}{ Total } & 551 & $459(84 \%)$ & $324(57 \%)$ & $319(57 \%)$ & $4(0.7 \%)$ & $2(0.4 \%)$ \\
\hline
\end{tabular}

*** Iban villages, **** Punan Village.

Table 2 .

\begin{tabular}{lccccc}
\hline Village surveyed & Sex & No. of samples & Roundworm & Hookworm & Whipworm \\
\hline \multirow{2}{*}{ Jitang } & M & 59 & $42(71 \%)$ & $28(47 \%)$ & $33(56 \%)$ \\
& F & 56 & $47(84 \%)$ & $21(38 \%)$ & $29(52 \%)$ \\
\hline \multirow{2}{*}{ Nyua } & M & 50 & $43(86 \%)$ & $31(62 \%)$ & $30(60 \%)$ \\
& F & 54 & $50(93 \%)$ & $27(50 \%)$ & $37(69 \%)$ \\
\hline \multirow{2}{*}{ Entap } & M & 64 & $57(89 \%)$ & $41(64 \%)$ & $28(44 \%)$ \\
& F & 75 & $72(69 \%)$ & $42(56 \%)$ & $39(52 \%)$ \\
\hline \multirow{2}{*}{ Kupak-kanyan } & M & 102 & $71(70 \%)$ & $81(79 \%)$ & $60(59 \%)$ \\
& F & 91 & $77(85 \%)$ & $53(58 \%)$ & $63(69 \%)$ \\
\hline \multirow{2}{*}{ Total } & M & 275 & $213(77 \%)$ & $181(66 \%)$ & $151(55 \%)$ \\
& F & 276 & $246(89 \%)$ & $143(52 \%)$ & $168(61 \%)$ \\
\hline
\end{tabular}


From this result, it can be said that the infection rates of roundworm, hookworm and whipworm are very high in these four villages.

Table 2 shows the result of fecal examinations for intestinal helminthes according to sex.

From this, Table, it is understandable that there is no remarkable difference between male and female.

In Table 3, the results above-mentioned are compared with the preceeding data by the 4 th and 5 th medical missions of Osaka University sent to the 1 st Division, Sarawak, in 1966 and 1967.

Table 3.

\begin{tabular}{clccc}
\hline Medical mission & Village surveyed & Roundworm & Hookworm & Whipworm \\
\hline \multirow{2}{*}{ 4th (1966) } & Kgn. Munggu Ai & $74 \%$ & $65 \%$ & $78 \%$ \\
& Kgn. Kepayan & $83 \%$ & $66 \%$ & $72 \%$ \\
\hline \multirow{2}{*}{5 th (1967) } & Kgn. Piching & $63 \%$ & $36 \%$ & $53 \%$ \\
& Kgn. Tai-e & $52 \%$ & $25 \%$ & $69 \%$ \\
\hline \multirow{2}{*}{6 th (1969) } & "Iban villages" & $87 \%$ & $53 \%$ & $55 \%$ \\
& Rn. Kupak-kanyan & $77 \%$ & $69 \%$ & $64 \%$ \\
\hline
\end{tabular}

\title{
PATHOLOGY AND HEMATOLOGY IN MICE GIVEN RH AND BEVERLEY STRAIN ORGANISMS OF TOXOPLASMA GONDII
}

\author{
MiNORU OKUGI, MASATO FURUYA, YoshiHIRo ITO, \\ NoRIKo MAEDA, YoshIKAZU OKA AND HUMIO OSAKI
}

Department of Parasitology, School of Medicine, Tokushima

University, Tokushima

In an attempt to elucidate the mechanism of infection in experimental toxoplasmosis in mice, the pathogenicity of $\mathrm{RH}$ and Beverley strains was compared.

Both sexes of $C F \# 1$ mice of approximately 60 days of age were used in this study being maintained at $22-24^{\circ} \mathrm{C}$ and $60-66 \%$ humidity. The animals were sacrificed $1,3,5,7,10$ and 20 days after intraperitoneal inoculation of $10^{4}$ trophozoites of RH strain or 50-100 cysts of Beverley strain, and anatomical, histopathological and hematological examinations were performed. Results obtained were as follows:

1. Significant inflammatory lesions were observed in organs of mice infected with RH strain organisms but on the contrary no noticeable change was seen in mice given Beverley strain cysts except for swellings of spleen and mesenteric lymph nodes. 